\title{
Revisiting the stratigraphy of the Mesoproterozoic Chhattisgarh Supergroup, Bastar craton, India based on subsurface lithoinformation
}

\author{
Arunangshu Mukherjee ${ }^{1,6, *}$, Ranjan Kumar Ray ${ }^{2}$, Dinesh Tewari ${ }^{3}$, \\ Vijay Kumar Ingle ${ }^{4}$, Bikram Kumar SahoO ${ }^{4}$ and M W Y Khan ${ }^{5}$ \\ ${ }^{1}$ Rajiv Gandhi National Ground Water Training and Research Institute, Central Ground Water Board, \\ Bhu Jal Bhawan, NH-IV, Faridabad 121 001, India. \\ ${ }^{2}$ Central Ground Water Board, Bhu Jal Bhawan, NH-IV, Faridabad 121 001, India. \\ ${ }^{3}$ Central Ground Water Board, Sector 27A, Madhya Marg, Chandigarh 160 019, India. \\ ${ }^{4}$ Rajiv Gandhi National Ground Water Training and Research Institute, Central Ground Water Board, \\ Tagore Nagar, Raipur 492 001, India. \\ ${ }^{5}$ School of Studies in Geology, Pt. Ravishankar Shukla University, Raipur 492 007, India. \\ ${ }^{6}$ Present Address: Upper Yamuna River Board, R K Puram, New Delhi 110 066, India. \\ ${ }^{*}$ Corresponding author.e-mail: mukherjeearunangshu@rediffmail.com
}

In the last 10 years, several teams of geologists from different institutions in India and abroad have vigorously investigated the Chhattisgarh basin (Bastar craton, India). Based on the new results and the lithologs of more than 350 water wells, resistivity and gamma-ray logs, and extensive geological traverses, we present a revised geological map, relevant cross sections, a new comprehensive stratigraphic column and a discussion of the new findings. Major outcomes of this revision are: (1) confirming the existence of two sub-basins (Hirri and Baradwar) and two depocentres; (2) establishing the age of the basin to be essentially Mesoproterozoic; (3) discarding the 'unclassified Pandaria Formation' and classifying the package of Pandaria rock units into Chandi, Tarenga, Hirri and Maniari formations in the Hirri subbasin; (4) accepting the 'group' status of the Singhora Group and the newly proposed Kharsiya Groups in the Baradwar sub-basin; (5) establishing an intrabasinal correlation of formations; (6) reappraising the thicknesses of the different formations; and (7) finding that the geometry of the basin is 'bowl-shaped', which is compatible with a sag model for the origin and evolution of the basin.

\section{Introduction}

The conventional wisdom that deposition in the unmetamorphosed Proterozoic sedimentary basins in India (Purana basins; figure 1) extended well into the 'Neoproterozoic', if not into the Lower Cambrian has been challenged with new radiometric dating. Recent geochronologic database (Rasmussen et al. 2002; Ray et al. 2002; Anand et al. 2003; Patranabis-Deb et al. 2007, 2008; Dongre et al. 2008; French et al. 2008; Malone et al. 2008; Pandey et al. 2008, 2012; Chalapathi Rao et al. 2010; Meert et al. 2010; Pradhan et al. 2010; Bickford et al. 2011a; Das et al. 2011; Mukherjee et al. 2012) indicate the closure of three (Chhattisgarh, Indravati, Vindhyan) of these basins to be about $1000 \mathrm{Ma}$ and that they opened at various times between 2000 and 1400 Ma. In the

Keywords. Lithostratigraphy; subsurface lithologs; black shale; Pandaria Formation; Chhattisgarh basin; India. 


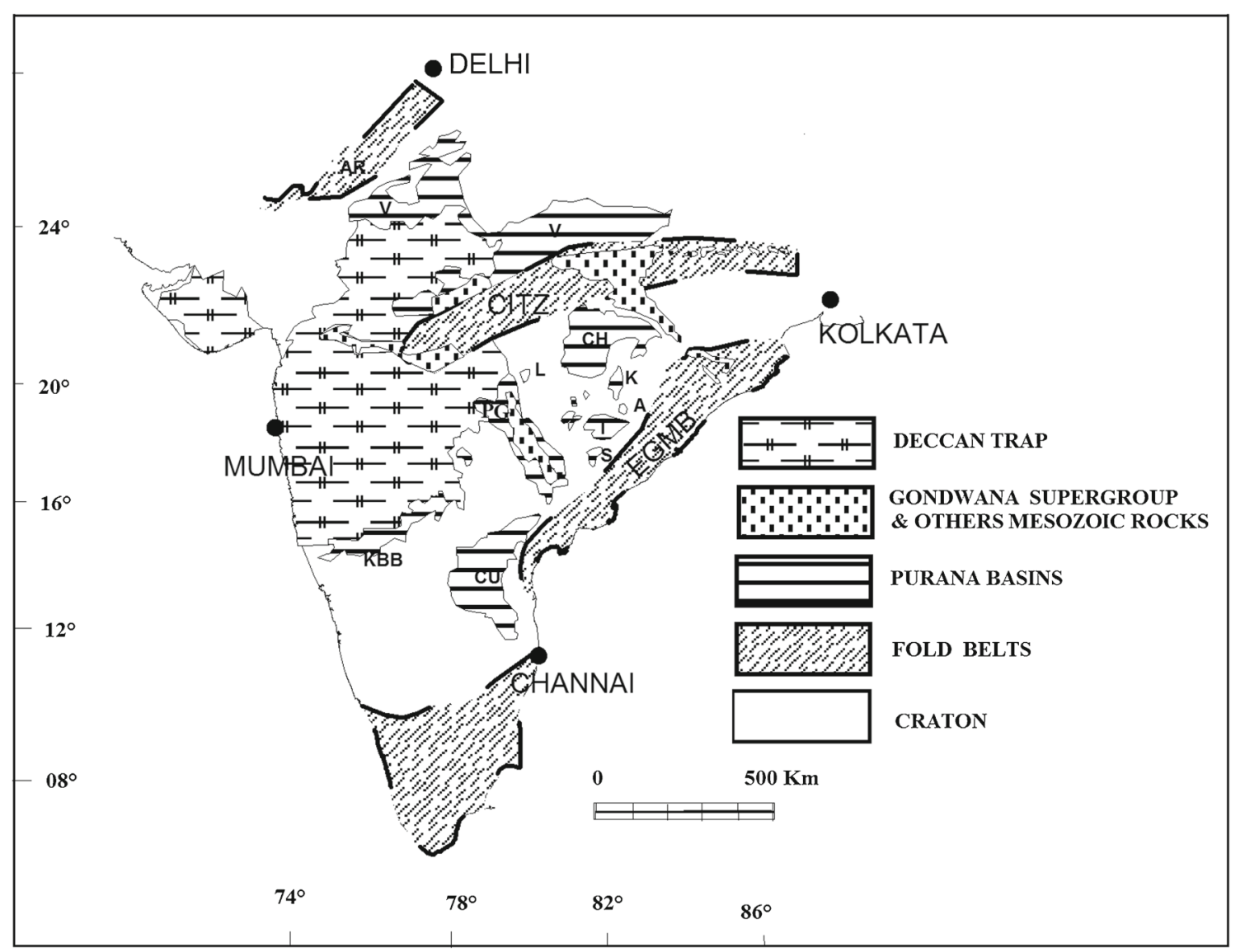

Figure 1. Geological map of the peninsular India showing the Purana basins: Vindhyan (V), Cuddapah (CU), Chhattisgarh $(\mathrm{CH})$, Pranhita-Godavari (PG), Indravati (I), Khariar (K), Ampani (A), Sabari (S), Lohara outlier (L) and KaladgiBhima-Badami (KBB). CITZ = Central Indian Tectonic Zone, EGMB = Eastern Ghats Mobile Belt (after Bickford et al. 2011a).

process, conflicts of opinion have emerged about the lithostratigraphic positions of a particular formation, and about the intra-basin and inter-basin correlations. The uncertainties are mainly due to (i) limited outcrops (ii) recurrent appearance of similar looking strata, and (iii) the lack of index fossils. The debate is particularly intense in the Chhattisgarh basin where parts of the existing stratigraphy and geological map (GSI 2005; Naqvi 2005) require extensive revision (Basu et al. 2008).

We have re-mapped key areas of the Chhattisgarh basin aided by voluminous subsurface data collected by the Central Ground Water Board (CGWB). The purpose of this paper is (1) to review and revise the lithostratigraphy of the Chhattisgarh basin, and (2) to present a revised geological map and the most reasonable lithostratigraphic succession.

The stratigraphy of the Chhattisgarh basin has been studied for long (Ball 1877) followed by Dutt (1964), Schnitzer (1969) and Murti (1987). But the complete succession with a map of the entire basin was first published by Das et al. (1992) who revised the stratigraphy while introducing several mappable formations. They divided the Chhattisgarh basin into two sub-basins namely the Hirri sub-basin and the Baradwar sub-basin (figure 2). They divided the Chhattisgarh Supergroup into three groups namely the Singhora, Chandarpur and Raipur groups in ascending order (Das et al. 1992, 2003). Recently, a new Kharsiya Group above the Raipur Group has been introduced while derecognizing the Singhora Group (Patranabis-Deb and Chaudhuri 2008; Dhang and Patranabis-Deb 2012). However, the overall sedimentary architecture of the Chhattisgarh basin is still not well established. For example, new geochronologic data show that the correlation and the order of lithounits in the western and the eastern parts of the basin differ vertically by at least $800 \mathrm{~m}$ (Bickford et al. 2011a; their figure 2). All investigators in the last 20 years have studied only parts of the basin. In this paper we incorporate data from more than 350 boreholes drilled by CGWB in the entire Chhattisgarh basin to present a revised geological map of the basin and relevant cross-sections to better understand the comprehensive stratigraphy of the basin (table 1 and figure 3 ). 


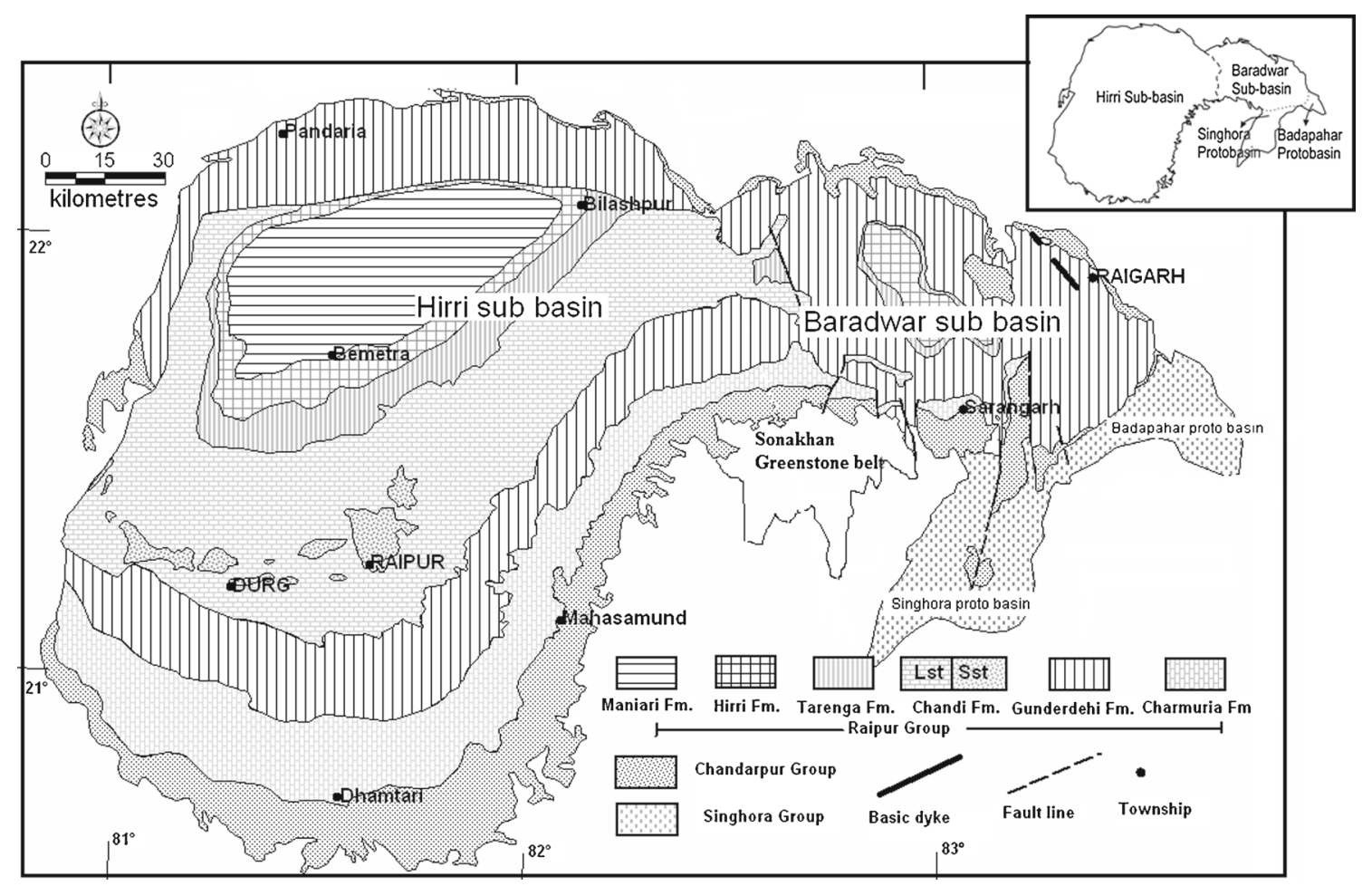

Figure 2. Geological map of the Chhattisgarh basin showing the Hirri and Baradwar sub-basins (after Das et al. 1992; GSI 2005).

\section{Methodology}

More than 350 boreholes for groundwater exploration were drilled covering the full area and all geological formations in the Chhattisgarh basin. Depths of the drill holes largely remained around $150 \mathrm{~m}$ but varied from 30 to $300 \mathrm{~m}$. Samples of drill-cuttings, generally less than $2 \mathrm{~cm}$ in size, were collected at regular intervals of $3 \mathrm{~m}$ in real time and lithologs were prepared accordingly. A limited number of core samples were obtained during drilling of production wells, which were used to check and validate the logs prepared from cuttings. Additionally, resistivity and gamma-ray logs from a few of the drill holes supplemented the data for interpretations. Further, in about $10 \%$ of the sites, several wells were drilled in clusters, which provided additional opportunity to reconfirm the lithologs and picking formational boundaries.

Despite some inherent limitations, this method of preparing lithologs is universally used in groundwater exploration and adds vastly to surface mapping especially where outcrops are sparse. Identification of rock type from small pieces of cuttings may at times be subjective and this may introduce errors in a litholog. However, errors can be corrected or minimized by comparing logs of adjacent boreholes, plotting the data on geological maps, and checking for compatibility. All data are archived in the CGWB office in Raipur, Chhattisgarh State.

\section{Stratigraphy of the Chhattisgarh Supergroup}

The concept of sub-basin and proto-basin was applied by Das et al. (1992) while preparing the geological map of the entire Chhattisgarh basin. The present work supports the existence of two sub-basins separated by a subsurface high and sedimentation in two depocentres. The Singhora area is part of the Baradwar sub-basin; the larger basin to the west is the Hirri sub-basin, i.e., the main basin (figure 2). The inferred subsurface high corresponds with the geophysical high observed by Singh et al. (2006). The term 'proto-basin' is now redundant and any basin eventually becomes proto-basin.

\subsection{Singhora Group}

The Singhora Group was first introduced by Das et al. (1992, 2003) and divided into four formations namely the arenaceous Rehatikhol, the argillo-calcareous and stromatolitic Saraipali, the arenaceous Bhalukona and the argillo-calcareous 
Table 1. Stratigraphic succession of the Chhattisgarh Supergroup.

\begin{tabular}{|c|c|c|c|}
\hline \multicolumn{4}{|c|}{ Chhattisgarh basin } \\
\hline \multicolumn{2}{|c|}{$\begin{array}{c}\text { Hirri sub-basin } \\
\left(\text { covers } \sim 25000 \mathrm{~km}^{2}\right)\end{array}$} & \multicolumn{2}{|c|}{$\begin{array}{l}\text { Baradwar sub-basin } \\
\left(\text { covers } \sim 8000 \mathrm{~km}^{2}\right)\end{array}$} \\
\hline Formation & Major lithology & Formation & Major lithology \\
\hline \multicolumn{4}{|c|}{ Alluvium/Laterite/Gondwana Supergroup /Intrusive rocks } \\
\hline \multicolumn{2}{|l|}{ Raipur Group } & \multicolumn{2}{|l|}{ Kharsiya Group } \\
\hline Maniari $(>300 \mathrm{~m})$ & $\begin{array}{l}\text { Gypsiferous purple shale } \\
\text { and dolomite }\end{array}$ & Nandeli & $\begin{array}{l}\text { Gypsiferous purple shale and } \\
\text { dolomite }\end{array}$ \\
\hline Hirri $(150 \mathrm{~m})$ & $\begin{array}{l}\text { Stromatolitic dolomite } \\
\text { and black shale }\end{array}$ & Sarnadih & Sandstone and conglomerate \\
\hline Tarenga $(>300 \mathrm{~m})$ & $\begin{array}{l}\text { Belha Member argillaceous } \\
\text { dolomite Dagauri Member } \\
\text { tuff }(993 \pm 8 \mathrm{Ma})^{1} \text { and } \\
\text { Kusmi Member shale }\end{array}$ & $\begin{array}{l}\text { Raipur Group } \\
\text { Churtela }\end{array}$ & $\begin{array}{l}\text { Purple shale and Sukhda } \\
\text { tuff }(1000 \mathrm{Ma})^{2}\end{array}$ \\
\hline Chandi $(670 \mathrm{~m})$ & $\begin{array}{l}\text { Stromatolitic limestone- } \\
\text { dolomite with Deodongar } \\
\text { Member sandstone-shale }\end{array}$ & Chandi & $\begin{array}{l}\text { Dolomite/stromatolitic } \\
\text { limestone }\end{array}$ \\
\hline $\begin{array}{l}\text { Gunderdehi } \\
(>300 \mathrm{~m})\end{array}$ & $\begin{array}{l}\text { Calcareous shale with Dotapar } \\
\text { Member sandstone }\end{array}$ & Gunderdehi & $\begin{array}{l}\text { Calcareous shale with } \\
\text { stromatolitic limestone }\end{array}$ \\
\hline $\begin{array}{l}\text { Charmuria } \\
\qquad(260 \mathrm{~m})\end{array}$ & $\begin{array}{l}\text { Flaggy limestone, shale } \\
\text { with Sirpur Member tuff (?) } \\
\text { and Ranidhar Member } \\
\text { cherty limestone }\end{array}$ & Sarangarh & Flaggy limestone and shale \\
\hline \multicolumn{2}{|c|}{ Chandarpur Group (130 m) } & \multicolumn{2}{|l|}{ Chandarpur Group } \\
\hline Kansapathar & Quartz arenite & Kansapathar (150 m) & Quartz arenite \\
\hline Chaporadih & $\begin{array}{l}\text { Glauconitic sandstone/ } \\
\text { silt stone and black shale }\end{array}$ & $\begin{array}{l}\text { Chaporadih } \\
\quad(\text { Gomarda })(600 \mathrm{~m})\end{array}$ & $\begin{array}{l}\text { Glauconitic sandstone/silt } \\
\text { stone and black shale }\end{array}$ \\
\hline \multirow[t]{3}{*}{ Lohardih } & $\begin{array}{l}\text { Subarkose with basal } \\
\text { conglomerate }\end{array}$ & Lohardih (150 m) & $\begin{array}{l}\text { Subarkose with basal } \\
\text { conglomerate }\end{array}$ \\
\hline & & $\begin{array}{l}\text { Singhora Group } \\
\text { Saraipali }(>300 \mathrm{~m})\end{array}$ & $\begin{array}{l}\text { Shale, tuff }(1405 \mathrm{Ma})^{3} \text { and } \\
\text { Stromatolitic limestone } \\
\text { with Bhalukona Member } \\
\text { sst and basic intrusive } \\
\text { (Diabase, } 1420 \mathrm{Ma})^{4}\end{array}$ \\
\hline & & Rehatikhol (30-75 m) & Sandstone with conglomerate \\
\hline \multicolumn{2}{|c|}{$\begin{array}{l}\text { Older basement } \\
\text { argarh Supergroup, Chilpi Group, } \\
\text { Group, Amgaon Group) }\end{array}$} & \multicolumn{2}{|c|}{$\begin{array}{c}\text { Older metamorphic and basements } \\
\text { (Rocks of Raigarh-Surguja metamorphic belt, } \\
\text { Sonakhan Group, Sambalpur Granites) }\end{array}$} \\
\hline
\end{tabular}

Note: The broken lines represent unconformity. The area in $\mathrm{km}^{2}$, thickness in $\mathrm{m}$ and radiometric age in Ma given in parenthesis. Age data sources: 1. Bickford et al. (2011a), 2. Patranabis-Deb et al. (2007), 3. Bickford et al. (2009, 2011b), (all 1 to 3 U-Pb SHRIMP age of magmatic zircons) 4. Das et al. (2011, Sm-Nd isochron age). 


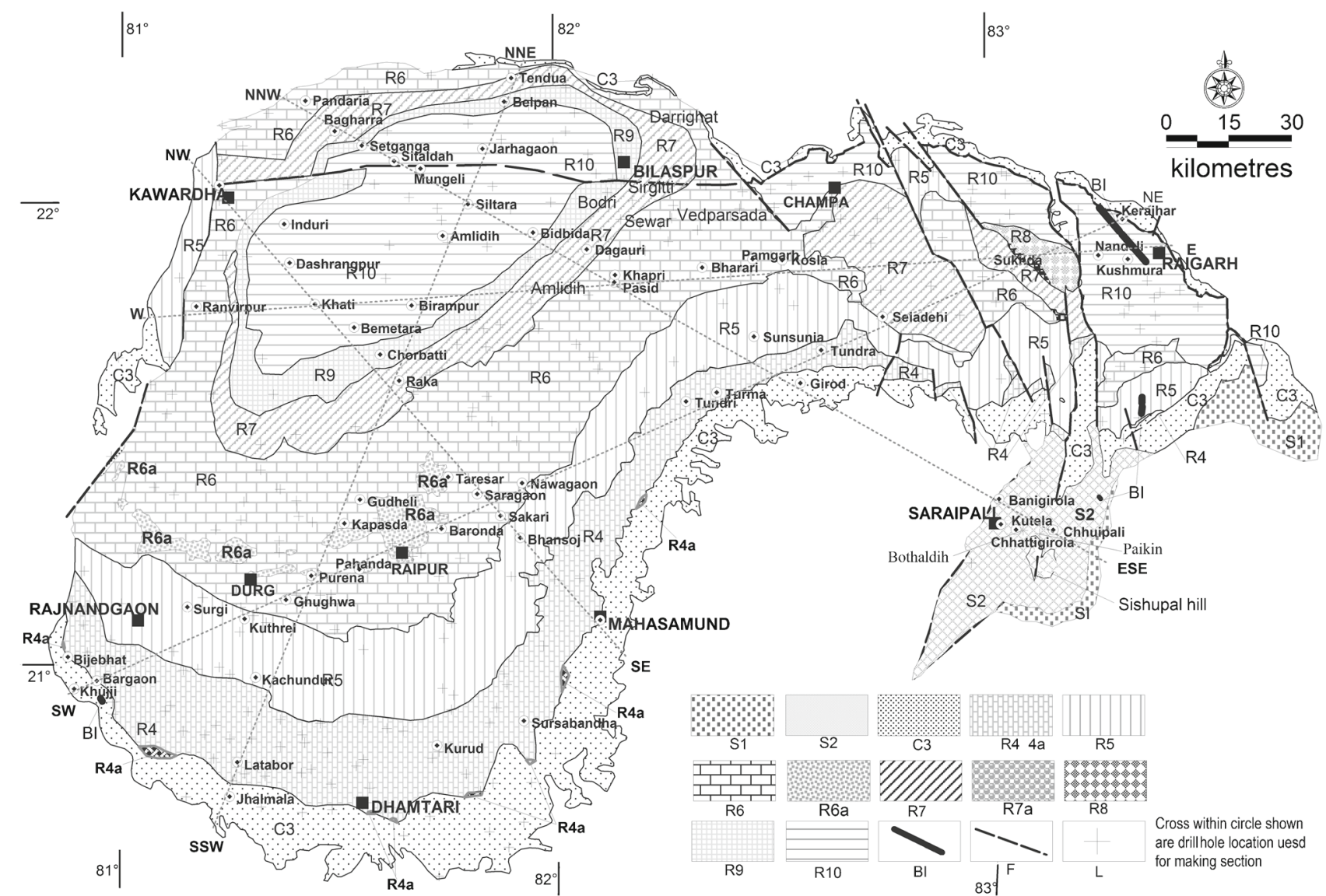

S1- Rehatikhol Fm, S2- Saraipali Fm (1 \& 2 Singhora Group); C3- Chandarpur Group; R4- Charmuria Fm, R4a- Charmuria tuff (Sirpur Member, Charmuria Fm), R5- Gunderdehi Fm, R6-Chandi Fm Lst - Dol, R6a- Chandi Sst-Sh (Deodongarh Member, Chandi Fm), R7- Tarenga Sh-Dol, R7a- Tarenga Tuff (7 \&7aTarenga Fm), R8- Sarnadih Fm, R9- Hirri Fm, R10- Maniari Fm (4-10 Raipur Group); BI- Basic intrusive; F- Fault line; L -Drillhole location ;

Section lines marked as feint dotted line with directions at end. ( $\mathrm{Fm}=$ Formation, Lst= limestone,Dol=dolomite,Sst=sandstone, Sh=shale)

Figure 3. Updated geological map of the Chhattisgarh basin (this work). Cross sections along the section lines shown in this map are given in figure 6.

Chhuipali Formation in ascending order. The Singhora basin is a small basin occupying about $2500 \mathrm{~km}^{2}$ area with maximum width of $34 \mathrm{~km}$. The Bhalukona sandstone is absent at Kutela and Chattigirola (figure 4). Based on drill hole data (150-300 m deep), we conclude Bhalukona as a member of argillo-calcareous Saraipali Formation, thereby restricting the two-fold division of Singhora Group into Rehatikhol (30-70 m) and Saraipali $(>300 \mathrm{~m})$ formations in ascending order (figure 3). This is evident in the Chattigirola drill hole in which the basement was met at a depth of only $275 \mathrm{~m}$ below the Saraipali and Rehatikhol formations (figures 3 and 4). Rhyolitic tuff beds (1405 \pm 9 Ma SHRIMP, Bickford et al. 2009, 2011a, Das et al. 2009) were identified in the Rehatikhol and Saraipali formations (Chakraborty 1997). Black shale is found intercalated within Saraipali Formation. Basic intrusives were reported from the Singhora area (Chakraborty et al. 2009; Das et al. 2011). The tuff unit of Singhoraghat, sandstone units and stomatolitic limestone units can be referred to as member within the Saraipali Formation.

\subsection{Chandarpur Group}

Rocks of the Chandarpur Group are widely exposed all along the southern margin of the Chhattisgarh basin lying unconformably over the crystalline basement. However, in the northern and western parts of the basin the rocks of the Chandarpur Group occur in fault controlled narrow escarpments (figure 3). This group has been divided into three formations, namely, the arenaceous Lohardih, the fine grained glauconitic arenaceous to argillaceous Chaporadih and the arenaceous Kansapathar formations in ascending order (Murti 1987; Das et al. 1992). The topmost Kansapathar Formation (also known as Kondkera at places) is persistent. Patranabis-Deb and Chaudhuri (2002, 2007) identified the Gomarda Formation below the Kansapathar Formation in the Raigarh area as roughly equivalent to the 


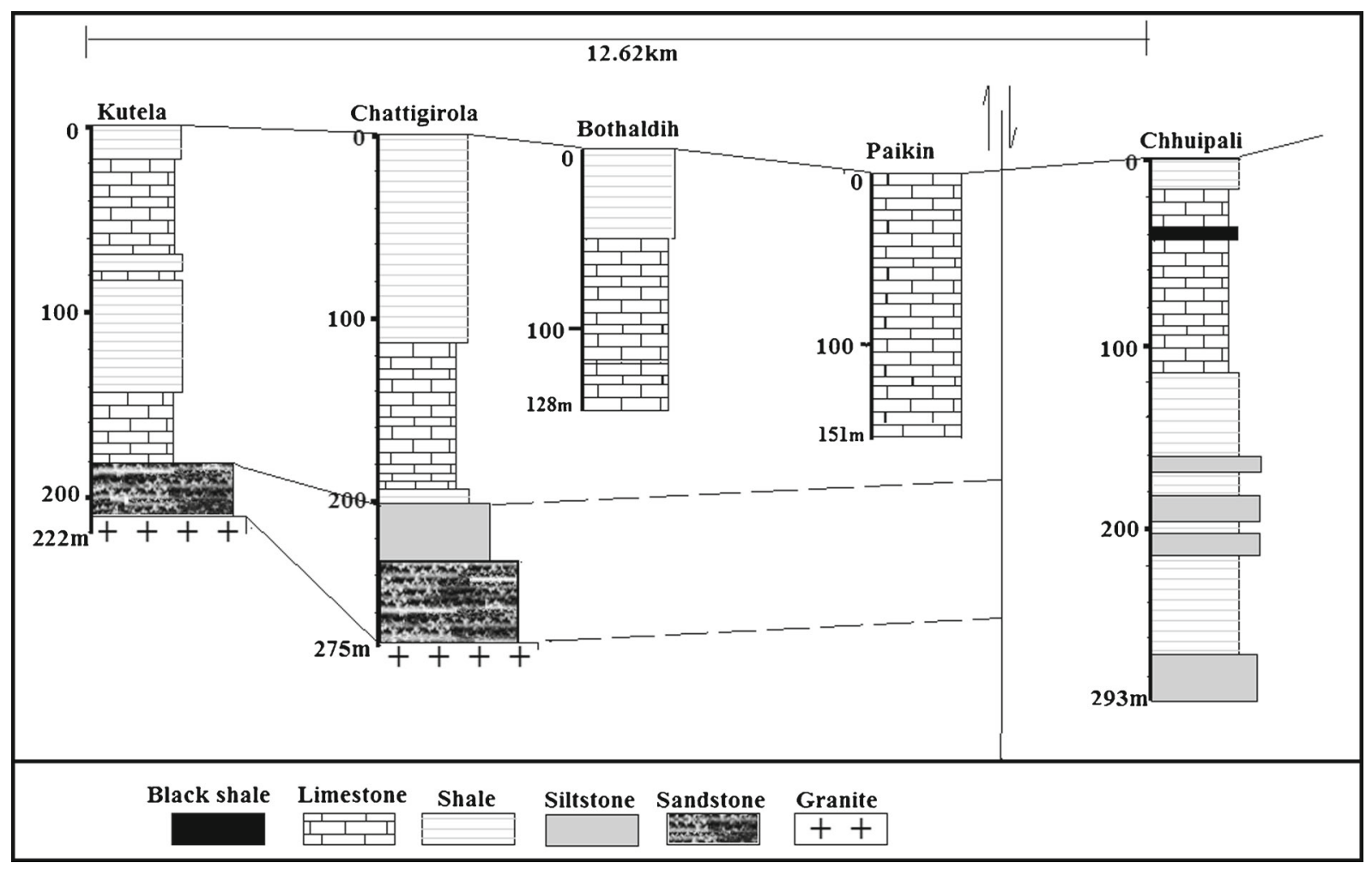

Figure 4. Litho columns of drill holes in the Singhora Group. Note the absence of sandstone unit at Kutela and Chattigirola within the argillo-calcareous sequence.

Chaporadih Formation of Das et al. (1992). The Chaporadih Formation is also widespread. Although basal conglomerates of Lohardih occur in patches, nevertheless feldspathic sandstones are widespread. Such distribution is consistent to their fan-delta depositional setting (Patranabis-Deb and Chaudhuri 2002). The formations of Chandarpur Group can be mapped at a 1:50,000 scale (e.g., Murti 1987; Khan and Mukherjee 1993). On average, the sand:shale ratio of this group is around 70:30. The outcrops are predominantly sandstone but shale, especially black shale is found at many locations and throughout the basin in the subsurface (figure 5). At Pipercheri, Khairwahi and Padkibhat drill holes, south of Latabor (figure 3), 33-89 $\mathrm{m}$ thick purple to black shale is recorded underlying the Charmuria Formation, followed by basement granite below, which is considered as equivalent to Chaporadih shales of Chandarpur Group. Lithologic cross sections suggest that the Chandarpur Group has a prism like geometry (figure 6). The thickness of the group in the Hirri sub-basin does not exceed $130 \mathrm{~m}$.

\subsection{Raipur Group}

The contact between the Chandarpur Group and the Raipur Group is sharp in both the Hirri and Baradwar sub-basins except at places south of Durg where it is gradational. Murti (1987) described the erosional contact between Chandarpur Group and Raipur Group at Birkoni and Tumgaon (north of Mahasamund) but PatranabisDeb and Chaudhuri (2008) do not report any unconformable contact between these two groups in the Baradwar sub-basin. The Raipur Group is well developed in the Hirri sub-basin and is divided into six formations (Das et al. 1992). All the formations are mappable even at a scale of 1:250,000 (GSI 2005, figure 2) and are discussed below.

\subsubsection{Charmuria Formation}

The Charmuria Formation, the oldest formation of the Raipur Group, is characterized by typical black flaggy limestone that grades to purple shale. The basal unit of the formation is either argillaceous (Sirpur Member) or cherty limestone (Ranidhar Member) at different places. XRD and clay mineral analyses, however, show that the 'shale' of the Sirpur Member is dominantly cryptocrystalline quartz. Khan and Mukherjee (1993) interpreted this quartz dominated rock as altered ash/tuff. The tuffs are at places light in weight, phosphatic and associated with chert bands. Murti (1987) interpreted the sediments of the Sirpur Member as detrital clay deposited at river-mouths. The wide occurrence of the Sirpur Member, however, makes 


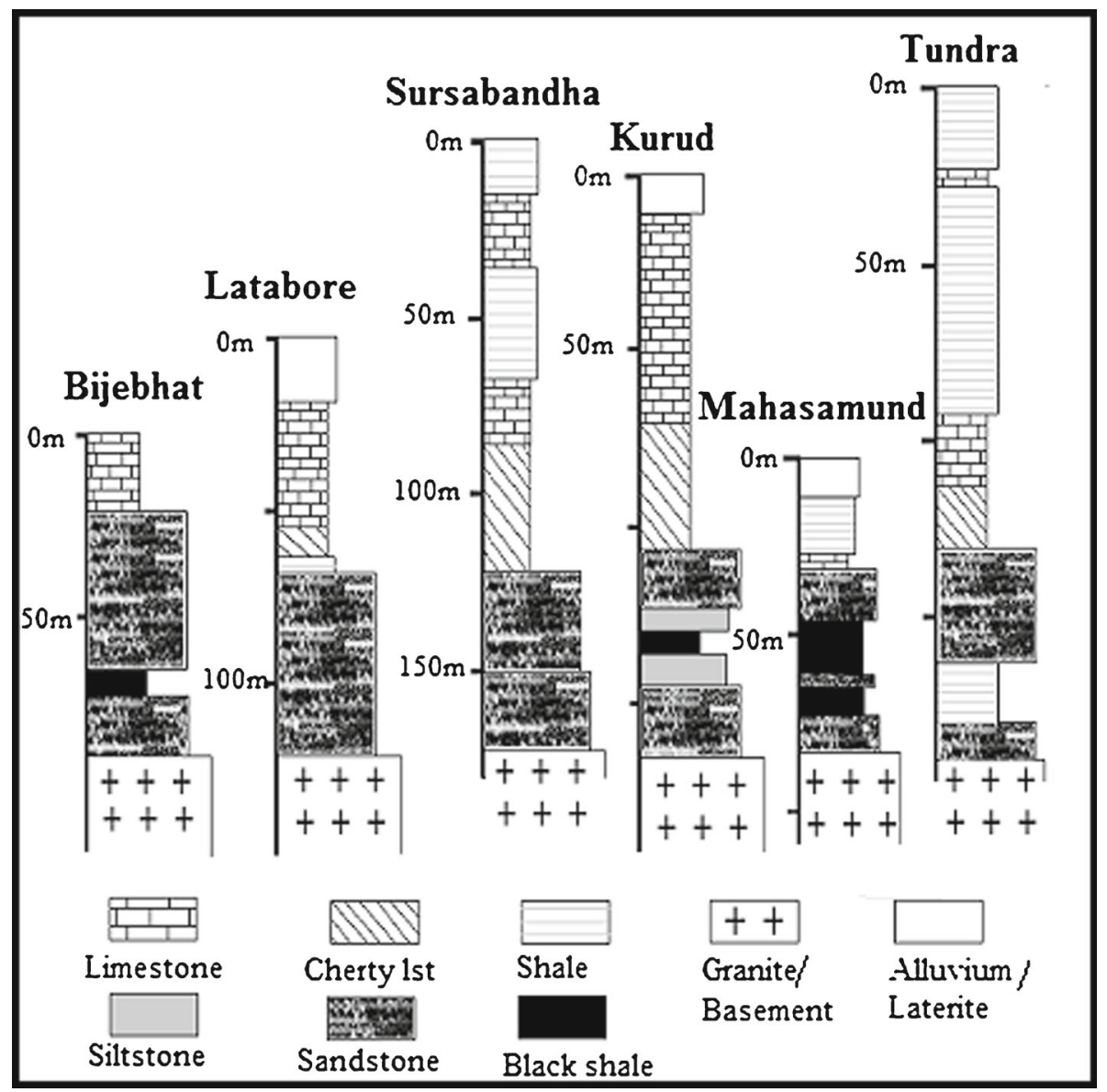

Figure 5. Litho columns of drill holes that penetrated the Charmuria Formation and the Chandarpur Group of rocks and touched the basement. Note the distribution of shale/black shale in the Chandarpur Group and cherty limestone of the Ranidhar Member of the Charmuria Formation.

us question Murti's hypothesis. At the surface, the Sirpur Member appears to occur in isolated patches all along the contact zone of the Chandarpur and Raipur Groups in the southern part of the Hirri sub-basin and forms low lying areas. Thick laterite $(3-10 \mathrm{~m})$ caps the areas occupied by the Sirpur Member. Therefore, exposures of the Sirpur Member can only be seen in excavations or dug wells, which give the impression of its being patchy. The presence of the Sirpur Member is observed at, but not restricted to, the Lohara-Sambalpur area, Jawargaon (Dhamtari) area, Belora-Bijaypur area, Fingeshwar, Pananduka-Sirpur areas and along the Dongargaon-Deori road (figure 3).

The Ranidhar Member of the Charmuria Formation is predominantly a cherty limestone, light green buff to cream in colour (figure 5). A purple shale unit found below the cherty limestone in the Baradwar sub-basin has been designated as Bijepur shale and included in the Raipur Group by Patranabis-Deb and Chaudhuri (2008). The revised boundary between the Chandarpur Group and Charmuria Formations in figure 3 is based on new mapping and using our subsurface data (figures 5 and 7 ). The thickness of this formation does not exceed $260 \mathrm{~m}$.

\subsubsection{Gunderdehi Formation}

The Gunderdehi Formation consisting mostly of calcareous purple to grey shale includes sandstone and siltstone lenses identified as the Dotapar Member. The maximum thickness of the Dotapar siltstone is found to be $5 \mathrm{~m}$ in a borehole at Baronda. In the Baramkela area south of Raigarh, thin bedded sandstone occurs above shale beds. Murti (1987) has reported occurrence of tuffaceous material and barite in Dotapar-Gobod area. Higher concentrations of $\left[\mathrm{SO}_{4}\right]^{2-}$ ions in a number of ground water samples in parts of the Gurur and Kurud area between Durg and Dhamtari is suspected due to presence of evaporites in this area as well. Facies variation and inter-fingering of shale and limestone in the Gunderdehi Formation is common. Patranabis-Deb and Chaudhuri (2008) reported stromatolitic limestone within the Gunderdehi Formation from the Baradwar sub-basin. The thickness of this formation varies from 75 to $240 \mathrm{~m}$ 
and rarely up to $300 \mathrm{~m}$. The previously proposed $430 \mathrm{~m}$ thickness for the Gunderdehi Formation by Murti (1987) seems to be too high.

\subsubsection{Chandi Formation}

The Chandi Formation dominated by purple to grey stromatolitic limestone is the largest formation (by thickness and area) in the Hirri sub-basin; but, it is very poorly developed in the Baradwar sub-basin. Chandi Formation is predominantly dolomitic at many places like around RamgarhVedparsada, Baradwar-Ghugri and BaramkelaSaria-Bonda areas. Subdivisions of the Chandi Formation into Niwari, Pendri and Nipania members were based mainly on colour (Murti 1987). The classification is useful, especially for mining, but only at local scale. Murti (1987) introduced this classification probably to equate his column with that of Schnitzer (1969). Incorporating the results of facies mapping and radiometric dating by Patranabis-Deb and Chaudhuri (2008) and Patranabis-Deb et al. (2007), we have revised the stratigraphy of the Baradwar sub-basin. The Saradih Formation (equivalent of Hirri Formation of Das et al. 1992) is now recognized as the Chandi Formation, and the Bamandihi Formation (equivalent to Chandi Formation of Das et al. 1992) is now recognized as the Tarenga Formation. Figure 3 incorporates these updates.

A substantial sandstone-shale unit, the Deodongar Member occurs within the Chandi Formation in the Hirri sub-basin (figure 3). The rocks of Deodangar Member were deposited as a regressive sequence (Mukherjee and Khan 1996). The 'Khairagarh Series sandstone' of Dutt (1964) is actually this Deodongar Member. At Piparia and Barhaitola (north of Rajnandgaon), the Deodongar Member sandstone-shale reaches a thickness of $67 \mathrm{~m}$ but is only $0-30 \mathrm{~m}$ thick in Raipur city (Mukherjee and Khan 1996). The sandstoneshale horizon is gently folded and shows domelike structure in excavations in and around Raipur. Apart from this, 1.5-4 $\mathrm{m}$ thick fine grained sandstone beds within the Chandi Formation were encountered during drilling at various places like Kapasda, Purena, etc., indicating occasional and local development of clastic facies within the overall chemogenic depositional environment. Limestone-shale intercalations are common and a thick (11-15 m) bed of black shale was encouterd during drilling at Darrighat and Vedparsada. Whole thickness of Chandi Formation could not be penetrated by any single borehole, the limit of which is $300 \mathrm{~m}$. The thickness of Chandi Formation is no less than $300 \mathrm{~m}$ and is reportedly $>650 \mathrm{~m}$ (Das et al. 1992).

\subsubsection{Tarenga Formation}

The Tarenga Formation consists dominantly of silty to very fine mudstone with minor calcareous, cherty and dolomitic beds. The formation is divisible into three members, i.e., the Kusmi, Dagauri and Belha, from bottom upward in the Hirri sub-basin. The Kusmi Member is the most widely occurring unit of the Tarenga Formation and consists of purple to grey-green shale with chert and limestone that are gypsiferous at places. The Dagauri Member is a marker horizon with typical green coloured tuffaceous shale dated at $1000 \mathrm{Ma}$ (U-Pb SHRIMP age of magmatic zircon, Bickford et al. 2011a). The thickness of the Dagauri Member is found to be up to $15 \mathrm{~m}$ at Amlidih and about $12 \mathrm{~m}$ at Raka (figures 3 and 6). The tuff of Dagauri Member was also encountered during drilling at Dagauri, Sirgitti, Bodri, Sewar, Hardikalan, Bishrampur, Birjhapur, Birampur and Setganga. The Belha Member consists of purple shale and argillaceous dolomite. Shale beds are found at various places like Raka, Amlidih, Bodri, and Setganga underlying Hirri Formation. The total thickness of the Tarenga Formation is found to be more than $300 \mathrm{~m}$. During the course of the present study, we have observed Tarenga Formation occurring to the north of the BilaspurKawardha fault line in the Hirri sub-basin.

In the Baradwar sub-basin, Das et al. (1992) mapped a large tract of shale as Raigarh Formation that they defined as equivalent to the Gunderdehi and Charmuria formations in the Hirri sub-basin. Subsequently, Patranabis-Deb et al. (2007) and Patranabis-Deb and Chaudhuri (2008) mapped the shale in the Janjgir-Champa area as part of the Churtela Formation that they placed near the top of the Chhattisgarh Supergroup. The stratigraphic position of the Sukhda tuff (Churtela Formation) was debated openly (Mukherjee and Sahoo 2003; Subba Rao et al. 2006; Basu et al. 2008; Mukherjee and Ray 2008; Patranabis-Deb et al. 2008; Mukherjee and Ray 2010). But, now all agree that the Sukhda tuff is equivalent to the tuff in the Dagauri Member in the Hirri sub-basin and is within the Tarenga Formation; magmatic zircons from both tuffs have been dated at ca. 1000 Ma (Bickford et al. 2011a).

\subsubsection{The elusive Pandaria Formation}

In the Hirri sub-basin, outcrops are sparse north of latitude $22^{\circ} \mathrm{N}$ except at basin margins. This probably led Das et al. (1992; their table 3) to lump the Charmuria, Gunderdehi, Chandi and the Tarenga formations under the umbrella term 'Pandaria Formation' (but see Mukherjee and Das 1993). In 
subsequent publications, the area has been shown as only Gunderdehi Formation (figure 2; GSI 2005) or as Charmuria Formation (Ramakrishnan and Vaidyanadhan 2008). Subsurface data now show that a long $\mathrm{E}-\mathrm{W}$ fault running immediately south of Bilaspur offsets the concentric outcrop pattern of the formations of the Raipur Group (figures 3 and 6). Thus, there is no need to invoke Pandaria as an umbrella term.

\subsubsection{Hirri Formation}

The Hirri Formation consists dominantly of greyblack dolomite and black shale. It is stromatolitic and gypsiferous at places. A 1-2 m thick arenite unit is found around Saida (adjacent to Bilaspur). Based on our borehole data, we have revised the position of the northern boundary of the Hirri Formation as mapped earlier by Das et al. (1992); the boundary is now shifted further north (figure 3). In the Baradwar sub-basin, what was earlier mapped as the Saradih Formation by Das et al. (1992), has now been identified as part of the Chandi Formation. According to our subsurface data and new mapping, the Hirri Formation is absent in the Baradwar sub-basin. This formation is restricted to the Hirri sub-basin. The thickness of this formation is found to be $150 \mathrm{~m}$, more than twice the earlier estimate of $70 \mathrm{~m}$. In summary, the map, thickness and the understanding of the Hirri Formation have been thoroughly revised.

\subsubsection{Maniari Formation}

This is the youngest formation of the Chhattisgarh Supergroup and consists of gypsiferous purple to pink shale and argillaceous dolomite. The lower part of the formation is more gypsiferous than the upper part. Our subsurface data show that a part of what was mapped as Pandaria Formation belongs to the Maniari Formation, i.e., the topmost unit of the Chhattisgarh basin. In the Hirri subbasin, a single borehole (at Birampur) penetrates the Maniari, Hirri and the Tarenga formations; the contacts are sharp (figures 6 and 7). The thickness of the Maniari Formation is found to exceed $300 \mathrm{~m}$ in drill holes near Sambalpur and Induri (figure 6).

In the Baradwar sub-basin, a sandstone unit unconformably overlies the Churtela Formation with a basal conglomerate having the clasts of the underlying Sukhda tuff (Basu et al. 2008). Patranabis-Deb and Chaudhuri (2008) mapped this unit as Sarnadih Formation, and the dominantly shale unit above as Nandeli Formation. These two formations, largely covering the area previously mapped as the Raigarh Formation in the Baradwar sub-basin, are equivalent to the Maniari Formation in the Hirri sub-basin. Patranabis-Deb and Chaudhuri (2008) have introduced a new group - the Kharsiya Group - to consist of the Sarnadih and the Nandeli formations. However, because the Sarnadih Formation consisting of sandstone and conglomerate is local, it occurs only in the Baradwar sub-basin and is not developed in the Hirri sub-basin where the Hirri Formation overlies the Tarenga Formation with a sharp contact, we consider this new group to be local.

\subsection{Basic intrusives}

The Chhattisgarh basin records intrusions of basic dykes spanning over $1000 \mathrm{Ma}$; the oldest is in the Calymmian (1.42 Ma, Sm-Nd isochron age) and the youngest corresponds to Danian (Deccan volcanism $\sim 65 \mathrm{Ma}$ ). The younger intrusives penetrate the Chandarpur or the Raipur Group of rocks in various parts of the basin (figure 3). Detailed list of these basic intrusives are available in published literature (Murti 1987; Subba Rao et al. 2007; Chalapathi Rao et al. 2010, 2011; Mukherjee and Ray 2010). The dolerite dyke at Mahrum, in the southern margin of the Hirri sub-basin (Mukherjee and Ray 2010) intrudes the Chandarpur sandstone and is associated with faults and quartz vein. The dykes of Mahrum and Dhanagarh have the same orientation (NNW-SSE). The KarrakotAmeri dyke is oriented N-S and the subcrop dyke at Raipur has an approximate $\mathrm{E}-\mathrm{W}$ orientation. Dhanagarh and Karrakot dykes intrude the Chandarpur Group and the Maniari Formation, whereas the dyke at Raipur and Janjgir cuts the Chandi Formation. A $100 \mathrm{~m}$ wide $\mathrm{N}-\mathrm{S}$ running intrusive dolerite has also been found along Nala section of village Bhalmar (Dungri, Orissa) within the siltstone/sandstone of Chandarpur Group. The extension of this dolerite is also marked at the road side of Dungri-Bhatli between 9 and $10 \mathrm{~km}$ stone in the hilly forested area. Older basic intrusives are reported cutting Singhora Group of rocks as mentioned above. A diabasic intrusive in Bandimal near the southwestern margin of the Singhora basin has been dated at $1421 \pm 23 \mathrm{Ma}$ (Das et al. 2011).

\subsection{Biostratigraphy}

In general, the upper carbonate platform of the Raipur Group in the Hirri sub-basin, provides the most information on the palaeobiology of the Chhattisgarh basin (Schnitzer 1969; Chatterjee et al. 1990; Moitra 1999, 2003a, b; Gupta 2004) although biogenic entities are found in the eastern sub-basins as well (Patranabis-Deb and Chaudhuri 2008; Chakraborty et al. 2012a). Stromatolites probably first appear as isolated 


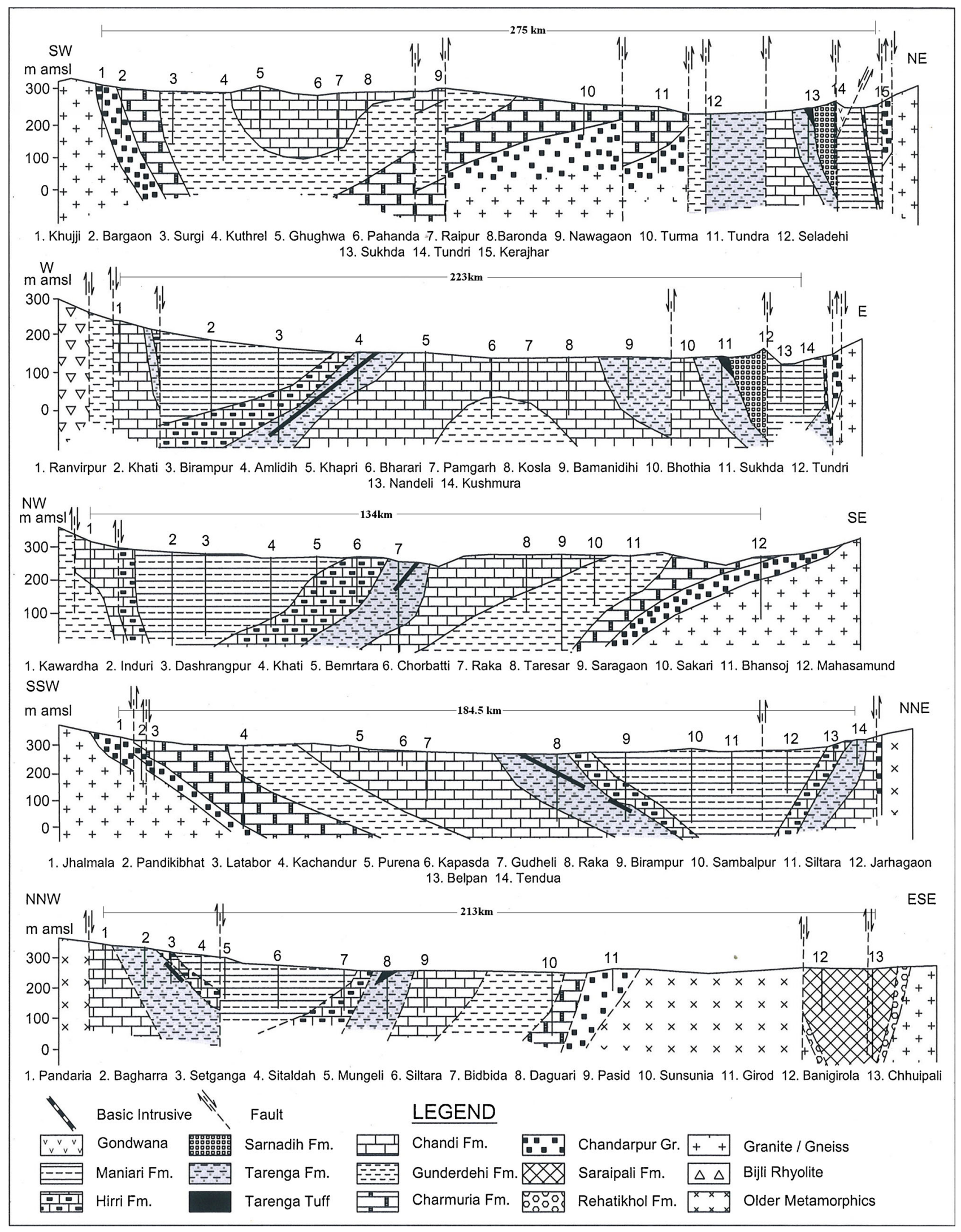

Figure 6. Cross sections drawn based on drill hole lithologs along section lines shown in the updated geological map (figure 3). Locations of drill holes are marked with vertical lines; the length of line represents the depth of the hole (m amsl $=$ meters above mean sea level, $\mathrm{Fm}=$ Formation, $\mathrm{Gr}=$ Group). Note: Beds are horizontal to low in dip but the apparent high dip in the section is due to high vertical exaggeration. 

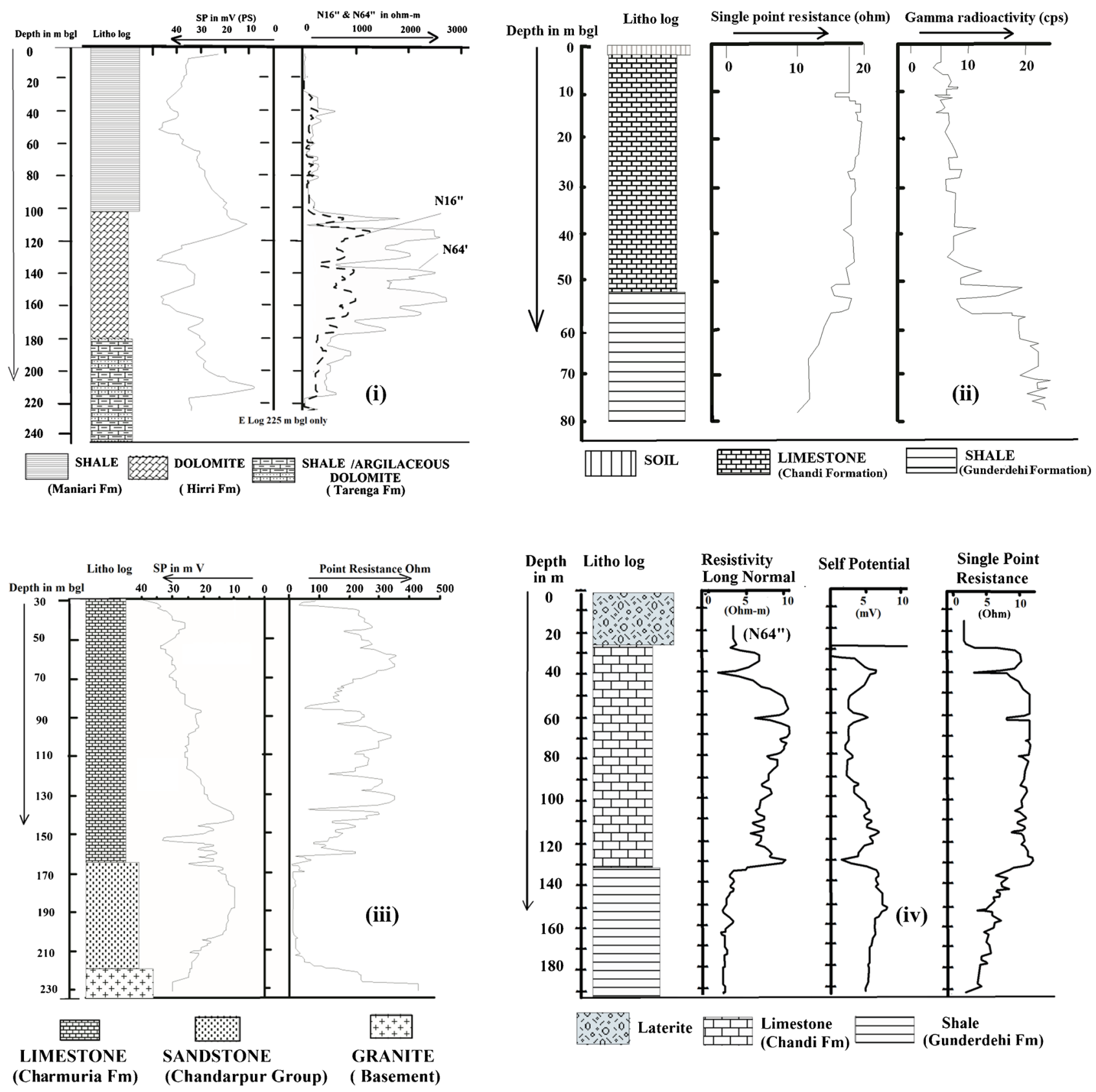

Figure 7. Composite lithologs from selected drill holes of the Chhattisgarh basin. Note the electrical and gamma logs that correspond to the litholog of the site (figure 3). The formational boundaries are well-picked by the corresponding changes in electrical properties. (i) Birampur: showing the occurrence of Maniari, Hirri and Tarenga formations in a single well. From drill cutting the contacts were marked at 102 and at $180 \mathrm{~m}$, respectively. (ii) Baronda: showing the contact of the Chandi Formation limestone and Gunderdehi Formation shale at $53 \mathrm{~m}$. (iii) Tumribod: Formational contacts are at $165 \mathrm{~m}$ (Charmuria Formation limestone and Kansapathar Formation sandstone), and at $220 \mathrm{~m}$ (Chandarpur Group sandstone and basement granite). (iv) Kawardha: The contact of the Chandi Formation limestone and the Gunderdehi Formation shale is at $130 \mathrm{~m}$.

mounds in the mud rocks (green shale) of the Saraipali Formation in the Singhora Group, which Das et al. (2003) claim to suggest an early Riphean age. The Charmuria Formation (lower Raipur Group) in general does not show any stromatolite in macroscopic studies. A few stromatolite mounds are common in the Gunderdehi Formation in the Baradwar sub-basin. The Chandi and Hirri formations, especially at places, are characterized by abundant stromatolites. Overall, the characters of stromatolite morphometry and assemblages change sufficiently in a stratigraphically vertical order, thus indicating biozones in the Chhattisgarh basin (Moitra 2003a). Taxonomic identification of the stromatolites suggests that the age of the Chandi Formation is close to the Precambrian/ 
Cambrian boundary. Such taxonomic assignments have prompted biostratigraphic correlations across all Purana basins in peninsular India (e.g., Moitra 2003a; Gupta 2004). It is beyond the scope of this paper to re-examine the taxonomy of stromatolites in the Chhattisgarh basin and the proposed correlations. Suffice it to state that recent geochronological data (Patranabis-Deb et al. 2007; Bickford et al. 2009, 2011a, b; Das et al. 2009) do not support any Neoproterozoic age for the stromatolite-bearing units in this basin.

Das and Rao (1992) describe a set of microscopic features that they identify as burrows from the Charmuria limestone. It will require a team of independent palaeontologists to re-examine the specimens as well as collect new samples and agree that the markings are indeed burrows. If true, then these could be the trace-fossils of the oldest motile multicellular life forms, i.e., metazoans. There are other independent reports of morphologic features that have been suspected, if not claimed, to be fossils of eukaryotic organisms and even possible metazoans in different units of the Chhattisgarh succession (e.g., Dubey 2002; Moitra 2003b; De 2007). On the other hand, Khan and Mukherjee (2004) describe phosphatised microbial mats from the Charmuria Formation although they stop short of explicitly contradicting the palaeontologically assigned Neoproterozoic age for the Chhattisgarh succession. Regardless, recent work by Banerjee et al. (2009) and Bengtson et al. (2009) show that microbial constructs, mineralized or not, can be and are easily confused and misidentified as metazoan impressions or constructs. One must also consider that with newer discoveries and new radiometric ages, the age-ranges of fossils are liable to be extended as is common in biostratigraphy (e.g., Ghosh et al. 2007).

\section{Discussion}

\subsection{Inter-basin and intra-basin correlation of stratigraphic successions}

Correlation of Purana sedimentary basins of peninsular India until the end of the last century was based on similarity in litho-assemblages, petrological characteristics and depositional environments of a few common formations in the absence of body fossils and absolute age data. In the larger Purana basins (e.g., Vindhyan, Cuddapah and Chhattisgarh) depocentres shifted through time and sedimentation patterns were different in different sub-basins. Therefore, it is essential to establish intrabasinal correlation to understand the complete lithostratigraphic succession in a basin. The Chhattisgarh basin consists of a western $\left(\sim 25000 \mathrm{~km}^{2}\right)$ Hirri sub-basin and an eastern $\left(\sim 8000 \mathrm{~km}^{2}\right)$ Baradwar sub-basin (figure 2). Hirri sub-basin is well developed, less disturbed and fairly well understood, whereas the Baradwar sub-basin is ill developed, largely affected by numerous faults (figure 3 ) and is thus poorly understood. The complexities are multiplied due to poor outcrops, nearly horizontal structural dips, dominance of purple colour and cyclic repetition of lithounits. Paucity of marker horizons and index fossils has aggravated the complexity. For example, purple coloured broadly similar-looking shale of Gunderdehi, Tarenga and Maniari formations are well separated by purple-grey stromatolitic limestone of Chandi Formation and dark dolomite of Hirri Formation in the Hirri sub-basin. However, in the absence of these carbonate units, misidentification of shale units in the Baradwar sub-basin in the field has led to mapping errors that are understandably not reconciled yet (Das et al. 1992; GSI 2005; Naqvi 2005; Patranabis-Deb et al. 2007, 2008; Mukherjee and Ray 2008, 2010; Bickford et al. 2011c; Chakraborty et al. 2011, 2012b). The intrabasinal correlation of the Chhattisgarh basin, as we understand it, is presented in table 1 .

Das et al. (1992, 2003) introduced the Singhora Group as the basal group of the Chhattisgarh Supergroup (figure 2). On the other hand, Patranabis-Deb and Chaudhuri (2002, 2007, 2008) and Dhang and Patranabis-Deb (2012) have remapped the Baradwar sub-basin and derecognized the Singhora Group; they assign the rocks in the Singhora area to the Chandarpur Group (see below). Regardless of this disagreement, radiometric dating of basal units of the Singhora Group at ca. $1400 \mathrm{Ma}$ and from near the top of the Raipur Group at ca. $1000 \mathrm{Ma}$ (Patranabis-Deb et al. 2007; Das et al. 2009; Bickford et al. 2011a, b) establishes the depositional age of the Chhattisgarh Supergroup to be essentially Mesoproterozoic.

Bickford et al. (2011b) found only ca. $2500 \mathrm{Ma}$ detrital zircons in the Rehatikhol Formation, (Singhora Group) and the Lohardih Formation (Chandarpur Group) and none in the age-range between 1400 and $1500 \mathrm{Ma}$ in the latter. They inferred that there was very likely no erosional unconformity between the two groups, which would have excavated zircons from the Singhora tuff and deposited them in the sandstone of Lohardih Formation. They are of the opinion that the two groups are time equivalent, developed on the same crystalline basement and do not represent two separate stratigraphic levels. According to Dhang and Patranabis-Deb (2012), field mapping and other stratigraphic evidence also indicate that the Singhora Group is a lateral extension of Chandarpur Group in the Singhora area. This 
hypothesis is strongly contested by the Delhi University researchers and associates (Das et al. 2009, 2011; Chakraborty et al. 2011; Saha et al. 2012). Based on their detailed study and structural mapping of a part of the Singhora area, Saha et al. (2012) infer that the Singhora Group is pervasively deformed, but that the rocks of the overlying Chandarpur Group remain undeformed; hence, they infer that there must be an erosional unconformity between these two sets of rocks supporting separate 'group' status of Singhora and Chandarpur. The present study, based on the comparison of drill hole lithologs and sections, confirms the presence of a crystalline basement below both the Rehatikhol Formation (Singhora Group) and the Lohardih Formation (Chandarpur Group). None of the drilled wells encountered Singhora Group of rocks directly below the Chandarpur Group. However, the deformation of the rocks in the Singhora area took place prior to the intrusion at 1420 Ma. Therefore, the deformation did not affect the younger Chandarpur or Raipur groups of rocks. Pervasive deformation and restricted occurrence of the older intrusives only in the Singhora Group clearly suggest its separate and independent status within the Chhattisgarh Supergroup. We agree that the putative angular unconformity between the Chandarpur and Singhora groups represents a hiatus.

The Baradwar sub-basin is also faulted intensively. A fault running N-S divides the Singhora Group at least through the Sishupal hill. Truncation of beds along this N-S fault can be seen at Sishupal hill even in Google Earth images. Further fault related crushed breccia is observed along the eastern fringe of the elongate hill (situated to the left of Shishupal Hill), when approached from the village Kotdwari. Dislocation of strata, in the subsurface along $\mathrm{E}-\mathrm{W}$ litho section across this fault line, parallel to Saraipali-Chhuipali road is evident (figure 4). The pointed tip of Singhora basin at the southern edge could be a result of a set of faults intersecting each other. These faulting can explain the discontinuation of the Rehatikhol Formation in southeastern part of basin and the absence of surface exposure of this formation to the west of the Singhora area.

The newly proposed Kharsiya Group is underlain by the Churtela Formation and consists of two formations - Sarnadih and Nandeli formations (Patranabis-Deb and Chaudhuri 2008). However, Sarnadih and Nandeli formations are identified only in the Baradwar sub-basin. In the Hirri subbasin, no unconformity between the Tarenga and the Hirri formations can be established. Accordingly, in the stratigraphic succession presented in this paper, the Kharsiya Group is shown at the top of the succession in Baradwar sub-basin and the
Raipur Group is shown at the top of the main Hirri sub-basin (table 1).

\subsection{Evolution of the Chhattisgarh basin}

The geometries of various formations as depicted in the cross sections derived from surface and borehole data imply the dominance of layer-cake stratigraphy, except at basin-margins, and sagbasin tectonics (figure 6). To be sure, there is considerable variation of facies within each mappable formation but the latter appear to be stacked in a layer-cake fashion. Formation-mapping and our borehole data suggest that the main Chhattisgarh basin opened as an intracratonic sag with shallow peripheral faults, evolved in a bowl-shape while enduring occasional basic intrusions and rhyolitic volcanism, eventually started to shrink, and closed as an evaporite basin. Whereas sags represent crustal extension, we find no direct evidence of divergence of two plates underneath the Chhattisgarh basin. Remapping and identification of mappable formations in the hitherto unclassified catch-all 'Pandaria Formation', show the bowlshaped geometry in the northern part of the Hirri sub-basin. The presence of stromatolites and gypsum in various stratigraphic levels indicates that the basin remained shallow during the deposition of these sediments. Rate of deposition probably remained slow as is evident from the prolific development of stromatolites. The nearly NNW-SSE oriented Sonakhan greenstone belt in the southern cusp of the basin acted as a subsurface high that separated the two depocentres giving rise to two sub-basins as mentioned above (figure 3). The separation of the depocentres was likely accentuated from the beginning of the deposition of the Chandi Formation. It is possible that a subsurface fault was reactivated resulting in an uplift of the Sonakhan greenstones. The depositional slope of the younger formations in comparison to older formations was higher (figure 6), which provided additional accommodation space for the thicker younger formations. The cross sections also suggest that the rate of subsidence of the basin increased gradually until about $1000 \mathrm{Ma}$ when the basin began to close. Postdepositional faults, uplift, intrusions and weathering are responsible for the present configuration of the basin.

\section{Conclusion}

This revisiting of the stratigraphy of Chhattisgarh Supergroup requires three major corrections to the standard model (GSI 2005; Naqvi 2005). First, the unclassified 'Pandaria Formation' has been newly mapped and classified into Chandi, Tarenga, Hirri 
and Maniari formations; previously, Pandaria was listed as 'undifferentiated Charmuria-GunderdehiChandi-Tarenga formations'. Second, formations previously identified as Raigarh, Bamandihi and Saradih in the Baradwar sub-basin have been discarded. The package of rocks are now classified as Chandi, Churtela ( $\approx$ Tarenga), Sarnadih and Nandeli ( $\approx$ Maniari) formations. Third, in the absence of any mappable persistence of the 'Bhalukona Formation', the division of the Singhora Group into four formations has been revised into two formations, namely the Saraipali and the Rehatikhol formations. Apart from this, the thicknesses of various formations have been revised based on measured drill hole lithologs; and, formation-contacts have been defined more precisely. Significant litho units like black shale, tuff horizons and intrusive basic rock are highlighted in the present map. The sag theory of basin evolution is supported by the crosssections constructed from our borehole data. Intrabasinal correlation has been established with new data. The new comprehensive stratigraphic succession of the Chhattisgarh basin should aid in intrabasin stratigraphic correlation of Mesoproterozoic Purana basins of penninsular India.

\section{Acknowledgements}

Authors affiliated with CGWB are thankful to Shri Sushil Gupta, Chairman, CGWB, for according permission to publish the work. The logistic support and encouragement provided by the past Member (SAM) of CGWB Shri Subrata Kunar and the Regional Directors of CGWB, NCCR and RGI, Raipur are thankfully acknowledged. The authors are thankful to Prof. Abhijit Basu for his constant encouragement and suggestions and inspiration to write on this subject by compiling subsurface data. The paper is benefited from the comments of an anonymous reviewer. Compilation and interpretation of available CGWB data of groundwater exploration reported in this paper are solely the view of the authors and may not necessarily represent the view of the department they belong to.

\section{References}

Anand M, Gibson S A, Subbarao K V, Kelley S P and Dickin A P 2003 Early Proterozoic melt generation processes beneath the intra-cratonic Cuddapah Basin, southern India; J. Petrol. 44 2139-2171.

Ball V 1877 On the geology of the Mahanadi basin and its vicinity; Rec. Geol. Surv. India 10 561-567.

Banerjee S, Sarkar S, Eriksson P G and Samanta P 2009 Microbially related structures in siliciclastic sediment resembling Ediacaran fossils: Examples from India, ancient and modern; In: Microbial Mats (eds) Sechback J and Oren A, Berlin, Springer-Verlag, pp. 111-129.

Basu A, Patranabis-Deb S, Schieber J and Dhang P C 2008 Stratigraphic position of the $\sim 1000$ Ma Sukhda Tuff (Chhattisgarh Supergroup, India) and the $500 \mathrm{Ma}$ question; Precamb. Res. 167 383-388.

Bengtson S, Belivanova V, Rasmussen B and Whitehouse M 2009 The controversial 'Cambrian' fossils of the Vindhyan are real but more than a billion years older; Proc. Nat. Acad. Sci. 106 7729-7734.

Bickford M E, Basu A, Patranabis-Deb $\mathrm{S}$ and Dhang P C 2009 Depositional history of the Mesoproterozoic Chhattisgarh basin, central India: Constraints from new SHRIMP zircon ages; Geol. Soc. Am. Abstract Program 41541.

Bickford M E, Basu A, Mukherjee A, Hieptpas J, Schieber J, Patranabis-Deb S, Ray R K, Guheh R, Bhattacharya $\mathrm{P}$ and Dhang P C 2011a New U-Pb SHRIMP age of Dhamda Tuff in the Mesoproterozoic Chhattisgarh basin, peninsular India: Stratigraphic implication and significance of 1-Ga Thermal-Magmatic event; J. Geol. 119 $335-548$.

Bickford M E, Basu A, Patranabis-Deb S, Dhang P C and Schieber J 2011b Depositional history of the Chhattisgarh basin, central India: Constraints from new SHRIMP zircon ages; J. Geol. 119 33-50.

Bickford M E, Basu A, Patranabis-Deb S, Dhang P C and Schieber J 2011c Depositional history of the Chhattisgarh basin, central India: Constraints from new SHRIMP zircon ages: A reply; J. Geol. 119 553-556.

Chakraborty S 1997 Elucidation of the sedimentary history of the Singhora Group of rocks, Chhattisgarh Supergroup, MP; Rec. Geol. Surv. India 130 184-187.

Chakraborty P P, Sarkar A, Das K and Das P 2009 Alluvial fan to storm-dominated shelf transition in the Mesoproterozoic Singhora Group, Chhattisgarh Supergroup, central India; Precamb. Res. 170 88-106.

Chakraborty P P, Das K, Tsutsumi Y and Horie K 2011 Depositional history of the Chhattisgarh basin, central India: Constraints from new SHRIMP zircon ages: A discussion; J. Geol. 119 549-552.

Chakraborty P P, Das P, Saha S, Das K, Mishra S R and Paul P 2012a Microbial mat related structures (MRS) from Mesoproterozoic Chhattisgarh Khariar basins, central India and their bearings on shallow marine sedimentation; Episods 35(4) 513-523.

Chakraborty P P, Das P, Das K, Saha S and Balakrishnan S 2012b Regressive depositional architecture on a Mesoproterozoic siliciclastic ramp: Sequence stratigraphic and Nd isotopic evidences from Bhalukona Formation, Singhora Group, Chhattisgarh Supergroup, central India; Precamb. Res. 200-203 129-148.

Chalapathi Rao N V, Anand M, Dongre A and Osborne I 2010 Carbonate xenoliths hosted by the Mesoproterozoic Siddanpalli Kimberlite Cluster (Eastern Dharwar craton): Implications for the geodynamic evolution of southern India and its diamond and uranium metallogenesis; Int. J. Earth Sci. (Geol. Rundsch) 99 17911804.

Chalapathi Rao N V, Burgess R, Lehmann B, Mainkar D, Pande S K, Hari K R and Bodhankar N $2011{ }^{40} \mathrm{Ar} /{ }^{39} \mathrm{Ar}$ ages of mafic dykes from the Mesoproterozoic Chhattisgarh basin, Bastar craton, central India: Implication for the origin and spatial extent of the Deccan Large Igneous Province; Lithos 125 994-1005.

Chatterjee N, Das N, Ganguly M and Chatterjee B 1990 Stromatolite based biostratigraphic zonation of Chandi Formation, Raipur Group, Chhattisgarh Supergroup, in and around Dhamdha-Nandini area, Durg District, 
Madhya Pradesh; Geol. Surv. India Spec. Publ. 28 400-410.

Das S S and Rao C N 1992 Micro-burrows from the Charmuria Formation, Madhya Pradesh, India; Palaios $\mathbf{7}$ $548-552$.

Das D P, Kundu A, Das N, Dutta D R, Kumaran K, Ramamurthy S, Thanavelu C and Rajaiya V 1992 Lithostratigraphy and sedimentation of Chhattisgarh basin; Indian Minerals 46(3-4) 271-288.

Das D P, Dutta N K, Dutta D R, Thanavellu C and Babu Rao K 2003 Singhora Group: The oldest Proterozoic lithopackage of eastern Bastar Craton and its significance; Indian Minerals 57(3-4) 127-138.

Das K, Yokoyama K, Chakraborty P P and Sarkar A 2009 Basal tuffs and contemporaneity of the Chattisgarh and Khariar basins based on new dates and geochemistry; J. Geol. 117(1) 88-102.

Das Priyabrata, Das Kaushik, Chakraborty P P and Balakrishnan S 20111420 Ma diabasic intrusives from the Mesoproterozoic Singhora Group, Chhattisgarh Supergroup, India: Implications towards non-plume intrusive activity; J. Earth Syst. Sci. 120(2) 223-236.

De C 2007 Study of the Proterozoic life of the Chattisgarh basin, Chattisgarh, in the light of early organic evolution, biostratigraphy and paleoenvironments; Rec. Geol. Surv. India 139 23-24.

Dhang P C and Patranabis-Deb S 2012 Lithostratigraphy of the basal part of the Chhattisgarh Supergroup around Singhora-Saraipali area and its tectonic implication; In: Cenozoic Tectonics, Seismology, and Palaebiology of the Eastern Himalayas and Indo-Myanmar Range (eds) Tiwari and Raghavendra P, Geol. Soc. India Memoir 77 493-515.

Dongre A, Chalapathi Rao N V and Kamde G 2008 Limestone xenolith in Siddanpalli Kimberlite, Gadwal granitegreenstone terrain, eastern Dharwar Craton, southern India: Remnant of Proterozoic platformal cover sequence of Bhima/Kurnool age?; J. Geol. 116 184-191.

Dubey R 2002 Search and study of body fossils, medusoids and trace fossils in the upper part of Chhattisgarh Basin along with stable carbon isotope ratio study (abstract?); Rec. Geol. Surv. India 135(6) 8.

Dutt N V B S 1964 A suggested succession of the Purana formations of the southern part of Chhattisgarh, Madhya Pradesh; Rec. Geol. Surv. India 93 143-148.

French J E, Heaman L M, Chacko T and Srivastava R K 2008 1891-1883 Ma southern Bastar-Cuddapah mafic igneous events, India: A newly recognized large igneous province; Precamb. Res. 160 308-322.

Ghosh S C, Pal T K and Nandi A 2007 First record of an aquatic beetle larva (Insecta: Coleoptera) from the Parsora Formation (Permo-Triassic), India; Palaentology 50 1335-1340.

GSI 2005 Geological and mineral map of Chhattisgarh (1:1000,000); Geol. Surv. India, Hyderabad.

Gupta S 2004 Stromatolites from the Proterozoic basins of central India: A review; Gondwana Geol. Mag. 19(2) 109-132.

Khan M W Y and Mukherjee A 1993 Geochemical constraints on the genesis of phosphate of Chhattisgarh Basin, Durg District, M.P; J. Geol. Soc. India 41 363373.

Khan M W Y and Mukherjee A 2004 Possible genetic significance of ultrastructures in Precambrian phosphorites of Chhattisgarh Supergroup, Durg District, Chhattisgarh; In: Precambrian crustal evolution and metallogenesis with special reference to central India (eds) Rai K L Patel and Suresh C (Hindustan Publishing: Delhi), Recent Researches in Geology 17 136-144.
Malone S, Meert J, Banerjee D M, Pandit M, Tamrat E, Kamenov G D, Pradhan V and Sohl L E 2008 Paleomagnetism and detrital zircon geochronology of the Upper Vindhyan Sequence, Son Valley and Rajasthan, India: A ca. 1000 Ma closure age for the Purana basins?; Precamb. Res. 164(3-4) 137-159.

Meert J G, Pandit M K, Pradhan V R, Banks J, Sirianni R, Stroud M, Newstead B and Gifford J 2010 Precambrian crustal evolution of peninsular India: A 3.0 billion year odyssey; J. Asian Earth Sci. 39 483-515.

Moitra A K 1999 Biostratigraphic study of stromatolites and microbiota of the Chhattisgarh Basin, MP, India; Palaeontologica Indica 51 1-95.

Moitra A K 2003a Stromatolite biostratigraphy in the Chhattisgarh basin and possible correlation with the Vindhyan basin; J. Palaeontol. Soc. India 48 215-223.

Moitra A K 2003b Possibility of finding metazoans in Chhattisgarh basin; Gondwana Geol. Mag. (Spec. Vol.) 7 395-400.

Mukherjee A and Das D P 1993 Discussion-reply: Lithostratigraphy and sedimentation of Chhattisgarh Basin; Indian Minerals 47 351-352.

Mukherjee A and Khan M W Y 1996 Detailed facies analysis of Deodongar Member, Chhattisgarh Supergroup, Durg-Raipur Districts, MP; Indian J. Earth Sci. 23(3) 139-146.

Mukherjee A and Ray R K 2008 SHRIMP Ages of zircon in the uppermost tuff in Chattisgarh basin in central India require $\sim 500 \mathrm{Ma}$ adjustment in Indian proterozoic stratigraphy: A discussion; J. Geol. 116(5) 537-539.

Mukherjee A and Ray R K 2010 An alternative view on the stratigraphic position of the $\sim 1$ Ga Sukhda tuff vis-a-vis chronostratigraphy of the Precambrians of central Indian Craton; J. Geol. 118 325-332.

Mukherjee A and Sahoo B K 2003 Groundwater potential in Janjgir-Champa district, Chhattisgarh state; In: Workshop on Emerging Challenges in Water Resources before Chhattisgarh State Proceeding Central Ground Water Board, Raipur, pp. A60-A75.

Mukherjee A, Bickford M E, Hietpas J, Schieber J and Basu A 2012 Implications of a newly dated ca 1000 Ma rhyolitic tuff in the Indravati basin, Bastar Craton, India; J. Geol. 120(4) 477-485.

Murti K S 1987 Stratigraphy and sedimentation in Chhattisgarh basin; In: Purana Basins of Peninsular India (ed.) Radhakrishna B P, Geol. Soc. India Memoir 6 239-260.

Naqvi S M 2005 Geology and the evolution of the Indian plate; New Delhi.

Pandey B K, Natarajan V, Veena Krishna and Pandit S A $2008 \mathrm{U}-\mathrm{Pb}$ and $\mathrm{Sm}-\mathrm{Nd}$ isotopic studies on uraniferous brecciated limestone from Bhima basin: Evidence for a Mesoproterozoic U-mineralization event in southern peninsular India; In: Significant milestones in the growth of geochemistry in India during the 50-year period: 19582008 (Abstract Volume), Geological Society of India and Atomic Minerals Division, Hyderabad, pp. 24-25.

Pandey U K, Sastry D V L N, Pandey B K, Madhuparna Roy, Rawat T P S, Rajeeva Ranjan and Shrivastava V K 2012 Geochronological (Rb-Sr and Sm-Nd) studies on intrusive gabbros and dolerite dykes from parts of northern and central Indian cratons: Implications for the age of onset of sedimentation in Bijawar and Chhattisgarh basins and uranium mineralization; J. Geol. Soc. India 79 30-40.

Patranabis-Deb S and Chaudhuri A K 2002 Stratigraphic architecture of the Proterozoic succession in the eastern Chattisgarh Basin, India: Tectonic implications; Sedim. Geol. 147 105-125. 
Patranabis-Deb S and Chaudhuri A K 2007 A retreating fan-delta system in the Neoproterozoic Chattisgarh rift basin, central India: Major controls on its evolution; Bull. Am. Assoc. Petrol. Geol. 91(6) 785-808.

Patranabis-Deb S and Chaudhuri A K 2008 Sequence evolution in the eastern Chhattisgarh basin: Constraints on correlation and stratigraphic analysis; The Palaeobotanist 57(1) $15-32$.

Patranabis-Deb S, Bickford M E, Hill B, Chaudhuri A K and Basu A 2007 SHRIMP ages of zircon in the uppermost tuff in Chattisgarh Basin in central India require $\sim 500 \mathrm{Ma}$ adjustment in Indian Proterozoic stratigraphy; J. Geol. 115 407-415.

Patranabis-Deb S, Bickford M E, Hill B, Chaudhuri A K and Basu A 2008 SHRIMP ages of zircon in the uppermost tuff in Chattisgarh Basin in central India require $\sim 500$ Ma adjustment in Indian Proterozoic stratigraphy: Reply; J. Geol. 116(5) 540-542.

Pradhan Vimal R, Meert Joseph G, Pandit Manoj K, George Kamenov, Gregory Laura C and Malone Shawn J 2010 India's changing place in global Proterozoic reconstructions: A review of geochronologic constraints and paleomagnetic poles from the Dharwar, Bundelkhand and Marwar cratons; J. Geodyn. 50 224242.

Ramakrishnan M and Vaidyanadhan R 2008 Geology of India, Bangalore; Geol. Soc. India 1\&2 552.

Rasmussen B, Bose P K, Sarkar S, Banerjee S, Fletcher I R and McNaughton N J $20021.6 \mathrm{Ga} \mathrm{U}-\mathrm{Pb}$ zircon age for the Chorhat Sandstone, Lower Vindhyan, India: Possible implications for early evolution of animals; Geology 30 103-106.
Ray J S, Martin M W, Veizer J and Bowring S A 2002 U-Pb zircon dating and Sr isotope systematics of the Vindhyan Supergroup, India; Geology 30 131-134.

Saha S, Das K, Chakrraborty P, Das P, Karmakar S and Mamtani M A 2012 Tectono-magmatic evolution of Mesoproterozoic Singhora basin, central India: Evidence for compressional tectonics from structural data, AMS study and geochemistry of basic rocks; Precamb. Res., doi: 10.1016/jprecamres.2012.03.004.

Schnitzer W A 1969 Zur Stratigraphie und Lithologie des nördlichen Chattisgarh-Beckens (zentral-Indien) unter besonderer Berückschtigung von Algenriff-Komplexen (Stratigraphy and lithology of the northern Chhattisgarh basin, central India, with special reference to algal reef complexes); Zeitschrift der Deutschen Geologischen Gesellschaft Jahrgang 1966 118(5) 290-295.

Singh C L, Lal T, Kumar A and Prajapati S K 2006 A study of geological setting of northeastern part of Chhattisgarh basin, Mahanadi Graben and Bilaspur-Raigarh-Surguja gneissic belt from gravity anomalies; J. Geol. Soc. India 68(6) 1093-1099.

Subba Rao D V, Mukherjee A, Khan M W Y and Sridharan D N 2006 New occurrence of intra basinal ignimbrites and welded tuffs from NE part of the Mesoto-Neoproterozoic Chhattisgarh basin, Bastar Craton: Implications for petrogenesis; J. Geol. Soc. India 68 589-592.

Subba Rao D V, Khan M W Y, Sridharan D N and Nagaraju 2007 A new find of younger dolerite dykes with continental flood basalt affinity from the Meso-Neoproterozoic Chhattisgarh basin, Bastar Craton, India; J. Geol. Soc. India 69 80-84. 